\title{
SISTEM PENGETAHUAN LOKAL MASYARAKAT CIDAUN - CIANJUR SELATAN SEBAGAI WUJUD ADAPTASI BUDAYA
}

\section{THE LOCAL KNOWLEDGE SYSTEM OF CIDAUN SOCIETY (SOUTH CIANJUR) ASA FORM OF CULTURAL ADAPTATION}

\author{
Rosyadi \\ Balai Pelestarian Nilai Budaya (BPNB) Bandung \\ Jalan Cinambo 136 Ujungberung - Bandung \\ e-mail: ochadroki@yahoo.com
}

\begin{abstract}
Abstrak
Sistem pengetahuan lokal, kearifan lokal atau kearifan tradisional (indigenous knowledge system) adalah pengetahuan yang khas milik suatu masyarakat atau budaya tertentu yang telah berkembang lama sebagai hasil dari proses hubungan timbal-balik antara masyarakat dengan lingkungannya. Masyarakat Cidaun di kawasan selatan Kabupaten Cianjur memiliki banyak keunikan, baik alam maupun penduduknya. Kondisi geografis Cidaun yang penuh tantangan, memberikan dorongan kepada masyarakatnya untuk lebih memahami lingkungan alamnya. Berbagai peristiwa dan fenomena alam yang mereka hadapi sehari-hari tersebut serta hubungan intensif dengan lingkungan alamnya telah membentuk sistem pengetahuan lokal yang sekaligus menjadi strategi adaptasi budaya masyarakat dalam menjalani kehidupan sehari-hari. Tulisan ini mengkaji sistem pengetahuan lokal masyarakat Cidaun dalam kaitannya dengan lingkungan tempat mereka berpijak dan melakukan aktivitas dalam menggeluti mata pencaharian hidupnya. Penelitian ini merupakan penelitian kualitatif serta menggunakan metode deskriptif dengan teknik memaparkan berbagai fenomena budaya, apa yang mereka alami, mereka ketahui, dan interpretasi mereka terhadap fenomena-fenomena yang dihadapi dalam kehidupan sehari-hari.
\end{abstract}

Kata kunci: pengetahuan lokal, adaptasi, budaya.

Local knowledge systems, indigenous or traditional knowledge are typical knowledge belonging to a particular community or culture that has evolved over many years as a result of the reciprocal relationship between people and their environment. Cidaun communities in southern Cianjur has many unique, both nature and its inhabitants. Cidaun geographical conditions challenging, giving encouragement to the people to better understand the natural environment. Various events and natural phenomena that they face daily and intensive built a relationship with the natural environment and has established a system of local knowledge as well as a strategy of cultural adaptation in living everyday life. This article examines the system of local knowledge Cidaun community in relation to the environment in which they stand and wrestle activity in his livelihood. This research is qualitative and descriptive methods with techniques explained various cultural phenomena, what they experienced, they know, and their interpretation of the phenomena encountered in daily life.

Keywords: local knowledge, adaptation, culture. 


\section{A. PEN DAHULUAN}

Sistem pengetahuan lokal atau sering juga disebut indigenous knowledge atau local knowledge adalah konsepkonsep mengenai segala sesuatu gejala yang dilihat, dirasakan, dialami ataupun yang dipikirkan, diformulasikan menurut pola dan cara berpikir suatu kelompok masyarakat. Sistem pengetahuan lokal berkenaan dengan aspek-aspek kehidupan masyarakat yang sangat luas. Ia bisa berkenaan dengan alam semesta (cosmology), flora, fauna, benda-benda, aktivitas, maupun peristiwa-peristiwa yang pernah terjadi.

Sistem pengetahuan lokal sangat terkait dengan lingkungan alam, sosial, maupun budaya di mana kelompok masyarakat itu hidup dan melakukan aktivitas-aktivitas utamanya dalam upaya mempertahankan hidup. Oleh karena itu, sistem pengetahuan lokal suatu kelompok masyarakat tidak mustahil akan berbeda dengan kelompok masyarakat lainnya. Dalam hal ini, sangat mungkin suatu fenomena yang sama, baik berupa benda, flora, fauna, maupun suatu peristiwa, akan diterjemahkan atau ditafsirkan berbeda oleh suatu kelompok masyarakat dengan kelompok masyarakat lainnya.

Dalam konteks kebudayaan, sistem pengetahuan lokal merupakan salah satu unsur budaya yang sifatnya universal, terdapat pada hampir semua kebudayaan, betapapun sederhananya kebudayaan itu.

Ade M. Kartawinata (2011: ix) menjelaskan mengenai konsep kebudayaan, bahwa kebudayaan dalam realitasnya sebagai satu istilah yang erat dengan kehidupan masyarakat. Karena kebudayaan, sebagaimana dikemukakan oleh para ahli antropologi, diciptakan manusia sebagai keseluruhan yang kompleks yang di dalamnya terkandung sistem pengetahuan, kepercayaan, seni, hukum, moral, adat istiadat, dan lain-lain kemampuan serta kebiasaan yang diterima oleh masyarakat secara berkelanjutan melalui proses enkulturasi, sosialisasi, dan internalisasi. Dengan demikian, setiap anggota masyarakat mempunyai pengetahuan mengenai kebudayaannya tersebut yang dapat tidak sama dengan anggota-anggota lainnya, disebabkan oleh pengalaman dan proses belajar yang berbeda dan karena lingkungan-lingkungan yang mereka hadapi tidak selamanya sama (Suparlan, 2005: 5).

Sebagai makhluk hidup, manusia paling mampu beradaptasi dengan lingkungannya dan selalu berupaya untuk memanfaatkan sumber-sumber yang ada untuk menunjang kebutuhan hidupnya. Hal itu menyebabkan adanya ikatan antara manusia dengan lingkungan alamnya. Ikatan itu memberikan pengalaman dan pengetahuan serta pikiran pada manusia, bagaimana mereka memperlakukan alam lingkungan yang mereka miliki. Mereka menyadari akan segala perubahan yang terjadi pada lingkungan sekitarnya, sekaligus mampu pula mengatasinya untuk kepentingannya. Mereka melakukan "ujicoba" dan mengembangkan pemahaman terhadap sistem ekologi di mana mereka tinggal. Pemahaman mereka tentang sistem alam yang terakumulasi biasanya diwariskan secara lisan, serta biasanya tidak dapat dijelaskan melalui istilah-istilah ilmiah. Pemahamanpemahaman ini yang kemudian disebut sebagai pengetahuan lokal (indigenous knowledge).

Sebuah tulisan dalam Antropologi Indonesia (Majalah Antropologi Sosial dan Budaya Indonesia) No. 55, XXII, 1998 yang diterbitkan oleh Jurusan Antropologi FISIP - UI, menjelaskan bahwa dalam dua dasawarsa terakhir, pengetahuan penduduk setempat yang dalam dunia internasional lazim disebut dengan indigenous knowledge menjadi pusat perhatian para ilmuwan, praktisi, pengambil kebijakan dan lembaga-lembaga donor. Dalam pelbagai arena akademis dan praktis, pengetahuan penduduk setempat menjadi agenda utama dalam pembahasan tentang kelemahan dan masalah yang timbul dalam pelbagai proyek pembangunan yang tidak mengacu pada atau melibatkan 
pengetahuan dan praktik-praktik penduduk setempat dalam pengelolaan lingkungan hidupnya (hal iii).

Keadaan inilah yang melatarbelakangi pentingnya dilakukan kajian mengenai sistem pengetahuan lokal masyarakat Cidaun di wilayah Cianjur Selatan sebagai sistem adaptasi masyarakat terhadap lingkungan alamnya.

Ada beberapa tujuan yang ingin dicapai melalui kajian ini, antara lain menggali dan menginventarisasi sistem pengetahuan lokal masyarakat Cidaun terkait dengan sistem mata pencaharian hidup mereka. Selanjutnya, dari hasil kajian ini diharapkan dapat diperoleh pemahaman yang utuh dan komprehensif mengenai keberadaan tradisi-tradisi masyarakat yang berpotensi bagi pelestarian lingkungan hidup.

\section{B. METODE PEN ELITIAN}

Penelitian ini merupakan penelitian kualitatif menggunakan metode deskriptif dengan cara memaparkan berbagai fenomena budaya yang ditemui di lapangan. Selanjutnya fokus kajian lebih diarahkan pada aspek-aspek yang terkait dengan sistem pengetahuan lokal yang dimiliki oleh masyarakat.

Bambang H. Suta Purwana (2004), dalam sebuah kertas kerjanya yang berjudul "Modal Sosial dan Pola Interaksi Sosial Komunitas Kampung Naga”, memaparkan mengenai metode kualitatif. Ia menjelaskan bahwa penelitian kualitatif melalui tiga tahapan pokok yang saling terjalin dalam bentuk yang sejajar, dan berlangsung pada saat sebelum, selama, dan sesudah pengumpulan data. Ketiga kegiatan tersebut yaitu: reduksi data, penyajian data, dan penarikan kesimpulan/verifikasi.

Reduksi data dimaksudkan sebagai proses pemilihan, pemusatan perhatian pada penyederhanaan, pengabstrakan, dan transformasi data "kasar" yang muncul dari catatan-catatan di lapangan. Reduksi data ini berlangsung terus-menerus selama kegiatan penelitian kualitatif ini berlangsung. Selama pengumpulan data berlangsung, terjadilah tahapan reduksi selanjutnya, yakni membuat ringkasan, mengkode, menelusur tema, dan membuat gugus-gugus informasi. Reduksi data atau proses transformasi ini berlanjut terus sesudah penelitian lapangan, sampai laporan akhir tersusun.

Reduksi data bukanlah suatu hal yang terpisah dari analisis, namun menjadi bagian dari analisis. Reduksi data merupakan suatu bentuk analisis yang menajamkan, menggolongkan, mengarahkan, membuang yang tidak perlu, dan mengorganisasi data dengan cara sedemikian rupa hingga kesimpulankesimpulan finalnya dapat ditarik dan diverifikasi.

Penyajian data dapat dibatasi sebagai penyusunan sekumpulan informasi yang memberi kemungkinan adanya penarikan kesimpulan dan pengambilan tindakan. Penyajian data dirancang guna menggabungkan informasi yang tersusun dalam suatu bentuk yang padu dan mudah diraih, sehingga penganalisis dapat melihat apa yang terjadi, dan menentukan apakah menarik kesimpulan yang benar ataukah terus melangkah melakukan analisis yang menurut saran yang dikiaskan oleh penyajian sebagai sesuatu yang berguna. Penyajian data dapat berupa teks naratif. Penyajian data juga merupakan bagian tak terpisahkan dari analisis. Merancang deretan dan kolom-kolom sebuah matriks untuk data kualitatif dan memutuskan jenis dan bentuk data yang harus dimasukkan ke dalam kotak-kotak matriks merupakan kegiatan analisis dan sekaligus juga merupakan kegiatan reduksi data.

Penarikan kesimpulan hanyalah sebagian dari satu kegiatan dari konfigurasi yang utuh. Kesimpulan juga diverifikasi selama penelitian berlangsung. Verifikasi yang dilakukan oleh subjek dan objek penelitian berguna untuk mengembangkan "kesepakatan intersubjektif". Makna-makna yang muncul dari data harus diuji kebenaran, kekokohan, dan 
kecocokannya, yakni yang merupakan validitasnya.

Data yang diperoleh adalah data kualitatif yang dijaring melalui teknik wawancara dan observasi, dan didukung dengan studi pustaka. Informan ditentukan secara purposif, yaitu tipe sampling yang didasarkan atas pertimbangan atau penilaian peneliti dengan asumsi bahwa informan yang dipilih representatif untuk populasi. Walaupun demikian, penilaian dan pertimbangan peneliti tidak lepas dari saran, pengetahuan, dan informasi yang diberikan tokoh-tokoh masyarakat, baik tokoh formal maupun tokoh informal. Mengingat hal itu, informan ditentukan secara berantai dari responden yang ditunjuk oleh tokoh masyarakat ke informan lain yang ditunjuk oleh informan pertama yang telah diwawancarai.

\section{HASIL DAN BAHASA N}

1. Fenomena Alam Cidaun di Kawasan Canjur Selatan

Cidaun adalah sebuah pemukiman penduduk berada dalam wilayah Cianjur Selatan, di Jawa Barat, letaknya di tepi pantai Lautan Indonesia. Kawasan ini beriklim tropis dengan curah hujan per tahun rata-rata 1.000 sampai $4.000 \mathrm{~mm}$ dan jumlah hari hujan rata-rata 150 pertahun. Dengan iklim tropis ini menjadikan kondisi alam Cianjur Selatan subur dan mengandung keanekaragaman kekayaan sumber daya alam yang potensial sebagai modal dasar pembangunan. Lahan-lahan pertanian tanaman pangan dan hortikultura, peternakan, perikanan dan perkebunan merupakan sumber kehidupan bagi masyarakat. Keadaan itu ditunjang dengan banyaknya sungai besar dan kecil yang dapat dimanfaatkan sebagai sumber daya pengairan tanaman pertanian.

Secara administratif Cidaun merupakan daerah administratif kecamatan yang masuk dalam wilayah pemerintahan Kabupaten Cianjur, Provinsi Jawa Barat. Kecamatan Cidaun meliputi wilayah seluas 56000 ha, terbagi ke dalam 14 desa yang satu sama lain letaknya berjauhan dan hanya bisa dicapai dengan kendaraan beroda dua atau jalan kaki. Beberapa desa yang berada di bawah wilayah administrasi Kecamatan Cidaun, antara lain: Desa Cidamar, Cisalak, Cimaragang, Mekarjaya, Kertajadi, Sukapura, Gelarpawitan, Karangwangi, Cibuluh, Karyabakti, Jayapura, Neglasari, Puncakbaru, dan Desa Gelar Wangi.

Menurut penuturan penduduk setempat, dulu di kawasan ini banyak hutan yang dianggap angker dan banyak dihuni binatang buas. Akibatnya, kalau hari sudah memasuki waktu zuhur, orang enggan bepergian ke desa lain karena suasananya sudah gelap. Akan tetapi kini, binatang-binatang buas ini sudah sangat jarang ditemui, mungkin sudah lenyap.

Sekalipun ancaman keangkeran hutan kini sudah tidak menjadi kendala lagi, kesulitan lain masih membentang, yaitu tidak lancarnya hubungan lalu-lintas. Kondisi jalan yang menghubungkan daerah ini dengan daerah-daerah di sekitarnya sangat memprihatinkan. Bukan sekadar jalan setapak, tapi jalan raya pun belum kondusif untuk dilalui kendaraan beroda empat. Sesungguhnya lahan pertanian di Cidaun umumnya subur dan hasil pertaniannya pun melimpah ruah. Akan tetapi sayang tidak didukung dengan sarana jalan dan infrastruktur lainnya, sehingga bagi penduduk setempat yang akan bepergian ke daerah lain atau ke luar kecamatan untuk menjual hasil pertanian, harus menanggung beban ongkos yang cukup besar.

Sarana infrastruktur lain di samping jalan yang kondisinya masih sangat memprihatinkan adalah bentangan sungai yang biasa digunakan sebagai jalan penghubung. Ada tujuh sungai yang harus dilewati, lima di antaranya belum berjembatan. Pada akhir tahun 1970-an awal tahun 1980-an pernah dipasang ponton pada Sungai Ciujung, tapi itu pun hanya bisa diseberangi kalau air sungai tidak meluap. Lama-kelamaan, ponton itu terbawa hanyut ke laut. Pada tahun-tahun berikutnya dibangun jembatan yang sangat 
sederhana, akan tetapi jembatan itu pun hanyut pula. Lebar sungai rata-rata di kawasan itu memerlukan jembatan yang panjangnya 30 meter, bahkan ada yang sampai 120 meter.

Beberapa bagian di kawasan Cidaun kondisinya berbukit-bukit. Pada turunanturunan yang menukik, tanahnya sering amblas. Daerah Cianjur Selatan terkenal akan gempa yang membuat letak tanah menjadi labil. Sehingga meskipun alam di sekitar cukup hijau oleh tetumbuhan vang merimbun, tak jarang jalanan setapak hilang karena tertimbun tanah longsor. Semua itu sering menggagalkan rencana membuat alur jalan yang memadai.

Di antara desa-desa yang ada di wilayah Kecamatan Cidaun, Desa Cidamar termasuk istimewa, karena beberapa tokoh di tingkat kecamatan berasal dari desa ini. Lingkungannya pun menampakkan keasrian. Rumah-rumah di desa ini memiliki pelataran yang rapi resik dengan arsitektur panggung. Desa Cidamar memiliki areal sawah milik seluas 167 ha, dan 85 ha perkebunan. Sisanya berupa tegalan, cagar alam, hutan lindung dan beberapa tanah garapan. Desa Cidamar memiliki 7 kadusunan yaitu: Dusun Kaum, Bobojong, Sukamaju, Girang, Babakan Garut, Bojonglarang, dan Margaluyu.

Penduduk Desa Cidamar pada umumnya adalah petani dan pencari ikan. Lahan pertanian di daerah ini sangat subur, sehingga setiap panen mengalami surplus padi maupun hasil kebun dan tegalan. Permasalahannya adalah, kendatipun mereka memiliki hasil pertanian yang melimpah, tetapi mereka sulit mendistribusikannya ke luar daerah karena kondisi jalannya yang sangat tidak memadai. Meskipun di kawasan itu membentang jalan yang terbuka lebar lewat Lautan Indonesia, bukan berarti hubungan ke daerah luar juga terbuka. Laut di kawasan ini terkenal ganas. Bahkan Pelabuhan Jayanti -- pelabuhan alam Cidaun--sejak lama porak-poranda oleh keganasan badai dan gelombang.
Perahu-perahu nelayan pun banyak yang hancur.

\section{Mata Pencaharian Masyarakat Cidaun}

Masyarakat Cidaun melakukan aktivitas-aktivitas guna memenuhi kebutuhan hidupnya dengan memanfaatkan sumberdaya alam yang terdapat di sekelilingnya. Lingkungan alam Cidaun yang berupa tanah pegunungan dan dibatasi oleh hamparan laut di deretan Pantai Selatan Jawa Barat, menjadi sumber bagi masyarakat untuk melangsungkan kehidupannya. Sesuai dengan kondisi lingkungan alamnya, masyarakat Cidaun memilih menjadi nelayan dan petani sebagai sumber mata pencaharian hidupnya.

\section{Nelayan}

Menurut Undang-Undang Perikanan Nomor 45 tahun 2009, nelayan merupakan orang yang mata pencahariannya melakukan penangkapan ikan. Nelayan kecil merupakan orang yang mata pencahariannya melakukan penangkapan ikan untuk memenuhi kebutuhan hidup sehari-hari yang menggunakan kapal perikanan berukuran paling besar 5 gross ton (5GT). Batasan ini mengindikasikan bahwa kehidupan nelayan bergantung pada hasil laut dan menjadikan nelayan sebagai komponen utama konstruksi masyarakat maritim Indonesia (Kusnadi, 2009).

Sebagaimana masyarakat pada umumnya, nelayan menghadapi sejumlah masalah sosial, politik, dan ekonomi yang kompleks (Kusnadi, 2009; Satria 2009). Salah satunya mengenai isu degradasi sumberdaya lingkungan, baik di kawasan pesisir, laut, maupun pulau-pulau kecil Pada banyak komunitas pesisir (nelayan), tradisi masih tetap dipertahankan bukan saja sebagai pegangan dan pedoman dalam mengelola pencahariannya sebagai nelayan, tetapi juga sebagai pendorong bahkan memberikan spirit bagi nelayan dalam menghadapi hidup kesehariannya (Nasrudin, 2011:171). 
Penduduk Cidaun yang tinggal di sekitar pantai Jayanti pada umumnya mempunyai mata pencaharian sebagai nelayan. Sektor perikanan meliputi pengembangan usaha perikanan air tawar dan laut. Kawasan Cianjur Selatan, khususnya Kecamatan Cidaun, cukup potensial dalam sektor perikanan, baik untuk usaha berskala kecil maupun besar. Beberapa faktor pendukungnya adalah jumlah penduduk yang relatif besar serta tersedianya lahan budi daya ikan air tawar dan ikan laut. Usaha pertambakan ikan dan penangkapan ikan laut serta budi daya udang pun memiliki peluang besar di sepanjang pantai Cidaun hingga Agrabinta. Terlebih setelah dibukanya jalur jalan yang menghubungkan Cidaun dengan daerahdaerah di sekitarnya, maka peluang usaha perikanan semakin terbuka. Pantai Jayanti yang dulunya sepi, sekarang setelah dibangun dermaga, pasar ikan, dan tempat pelelangan, daerahnya menjadi ramai. Jumlah nelayannya juga menjadi lebih banyak. Bertambahnya jumlah nelayan ini, karena untuk menjual ikan hasil tangkapan kini menjadi lebih mudah. Banyak pula bakul ikan yang datang, tidak hanya dari Cianjur, tapi juga dari daerah-daerah lain di luar Cianjur, bahkan yang datang dari Pangandaran.

Dalam melakukan aktivitas kenelayanannya, nelayan Cidaun masih menggunakan peralatan yang sangat sederhana. Beberapa peralatan yang biasa digunakan oleh masyarakat nelayan Cidaun di antaranya adalah:

- Sirib 'jala'; yaitu salah satu peralatan yang terbuat dari benang kenur, digunakan oleh nelayan untuk menangkap ikan dengan cara ditebar. Peralatan ini biasanya dibuat oleh nelayan sendiri, tetapi ada juga yang membelinya dari toko yang menyediakan peralatan melaut.

- Parahu 'perahu'; adalah alat untuk melaut atau berlayar, menangkap ikan di tengah laut. Perahu yang mereka gunakan untuk melaut terbuat dari kayu dengan bantuan mesin motor.
Ada pula nelayan yang menggunakan perahu tanpa mesin, sehingga mereka harus mendayungnya.

- Anco 'jala besar'; salah satu alat untuk menangkap ikan di laut maupun di sungai dengan cara ditebar, dibiarkan dan diangkat. Kegiatan menangkap ikan dengan cara ini disebut nganco 'menunggu'. Anco terbuat dari bambu dan jalanya terbuat dari benang kenur. Bagian lain dari anco adalah rakit, saung, jango, dan boboko.

- Rakit, adalah alat untuk melaut, menangkap ikan di sungai dan sebagai tempat tumpuan anco. Rakit terbuat dari beberapa batang bambu yang dirangkai berjejer ke samping, diikat dengan tali tambang. Selain untuk menangkap ikan, rakit juga biasa dipergunakan sebagai alat penyeberangan di sungai, digerakkan dengan cara didayung.

- Obor, adalah alat yang digunakan sebagai penerangan ketika menangkap ikan di malam hari. Obor terbuat dari sebilah bambu yang diisi dengan minyak tanah dan kain sebagai tempat menyalanya api.

Masyarakat nelayan di Cidaun melakukan kegiatan melautnya dengan bermodalkan sendiri. Nelayan yang ada masih bersifat tradisional, belum ada nelayan yang melakukan penangkapan ikan ke tengah laut dengan perahu atau kapal yang modern. Di Pantai Jayanti baru ada satu perahu milik warga, namun itu pun tidak digunakan ke tengah laut karena memang kondisinya yang tidak memungkinkan. Di Pantai Jayanti ombaknya sangat besar dan anginnya cukup kencang sehingga sangat membahayakan keselamatan bagi para nelayan. Selain itu, dipercaya bahwa Pantai Jayanti adalah salah satu pantai yang masih angker, jangankan melaut ke tengah, berenang di pinggir pantai saja tidak boleh saking berbahayanya. Terlepas dari kepercayaan itu, secara logika memang berbahaya karena pantainya sangat curam dan ombaknya besar. 
Modal yang mereka pergunakan dalam sekali menangkap ikan tidak terlalu besar sebab menangkap ikannya hanya di sekitar muara pantai saja. Hasil ikan yang mereka peroleh, mereka konsumsi sendiri dan dijual ke pasar. Ikan hasil tangkapan mereka pada umumnya didistribusikan ke daerah Sindangbarang, Cibinong, dan Cikadu.

Hasil melaut yang diperoleh oleh nelayan adalah berupa ikan. Selanjutnya, untuk dikonsumsi, ikan perlu diolah dan dibuat sebagai bahan makanan. Banyak macam makanan tradisional yang diolah dari bahan ikan. Makanan tradisional yang khas yang dihasilkan oleh masyarakat nelayan di Cidaun di antaranya adalah: pais impun (pepes impun), jalangkring (dendeng ikan impun atau rangginang impun), dan pais pelas.

\section{Petani}

Kondisi lahan pertanian tanaman pangan dan hortikultura, peternakan, perikanan dan perkebunan merupakan sumber kehidupan bagi masyarakat di Kecamatan Cidaun. Keadaan itu ditunjang dengan banyaknya sungai besar dan kecil yang dapat dimanfaatkan sebagai sumber daya pengairan tanaman pertanian. Tabel berikut menunjukkan rincian penggunaan lahan darat di kawasan Cidaun menurut peruntukannya.

Tabel 1. Komposisi Luas Tanah Darat Menurut Penggunaannya

\begin{tabular}{lll}
\hline No. & Jenis Tanah Darat & Luas/Ha \\
1. & Pekarangan & 1.843 \\
2. & Tegal/kebun & 3.605 \\
3. & Ladang/huma & 8.043 \\
4. & Padang rumput & -- \\
5. & $\begin{array}{l}\text { Sementara } \\
\text { diusahakan }\end{array}$ & 210 \\
6. & $\begin{array}{l}\text { Ditanami Pohon/Hutan } \\
\text { Rakyat }\end{array}$ & 4.463 \\
7. & Rutan Negara & 6.740 \\
8. & Perkebunan & 555 \\
9. & Lain-lain & 4.080 \\
10. & Rawa rawa yang & - \\
& Tidak Ditanami &
\end{tabular}

11. Tambak

12. Kolam/Tebat/ Empang 87 Jumlah 29.626

Sumber: Pemerintah Kabupaten Cianjur Dinas Perhubungan Komunikasi dan Informatika Kabupaten Cianjur.

Dengan kondisi seperti itu tidak heran jika sebagian besar penduduk Cidaun memilih mata pencaharian sebagai petani, dengan teknologi dan peralatan yang masih sederhana.

Secara umum, peralatan yang digunakan oleh masyarakat petani di Kecamatan Cidaun hampir sama dengan masyarakat petani di daerah-daerah lainnya di Jawa Barat. Beberapa peralatan yang biasa digunakan oleh masyarakat petani di Cidaun di antaranya adalah: pacul 'cangkul', wuluku/singkal, garu, belehem/garok, caplak, gerendel/gasrok, etem 'ani-ani', arit 'sabit', gebotan, congkrang 'sabit besar', parang, kored, gintiran padi, lesung dan alu, dan ancun.

Masyarakat petani di Kecamatan Cidaun seperti halnya masyarakat Sunda di daerah-daerah lain memiliki tradisi tahap-tahap pemeliharaan tanah garapan pertanian sebagai berikut:

- Ngawalajar, yaitu kegiatan membalikkan tanah. Pekerjaan ini biasa dilakukan dengan cara mencangkul atau dibantu dengan alat wuluku yang ditarik dengan kerbau atau sapi.

- Ngangler atau ngagaru, yaitu menggarap tanah sawah setelah diwuluku untuk menggemburkan dan meratakan tanah untuk segera ditanami padi.

- Tandur atau menanam padi, yaitu melakukan penanaman pada petakpetak sawah yang telah siap untuk ditanami.

- Ngagerendel, yaitu membersihkan rumput dengan menggunakan alat gerendel.

- Ngarambet, yaitu membersihkan dan merapihkan baris-baris padi. 
- Manen, atau menuai, yaitu memetik padi.

\section{Sistem Pengetahuan Lokal Masyarakat Cidaun}

Pengetahuan lokal yang dimaksud di ini adalah konsep-konsep masyarakat setempat mengenai berbagai fenomena alam yang mereka temui dalam kehidupan sehari-hari yang diinterpretasikan dan kemudian melahirkan sikap dan bentukbentuk perilaku tertentu. Interpretasi yang bersifat magis religius melahirkan sikap pemuliaan yang terwujud dalam bentukbentuk tabu atau pantangan adat. Sebaliknya interpretasi yang bersifat profan melahirkan sikap pengabaian yang dimanifestasikan dalam bentuk-bentuk perilaku eksploitatif terhadap sumber daya alam dan lingkungan.

Sebagaimana telah dipaparkan di muka, bahwa kondisi lingkungan alam Cidaun, telah menuntut masyarakat yang tinggal di dalamnya untuk menekuni mata pencaharian di bidang pertanian dan nelayan. Pengalaman hidup dalam beraktivitas kenelayanan maupun pertanian telah melahirkan sistem pengetahuan lokal di kalangan masyarakat yang terus berkembang dan diwariskan dari satu generasi ke generasi berikutnya.

Masyarakat nelayan di Cidaun mengenal gejala-gejala alam yang berkaitan dengan aktivitasnya sehari-hari maupun ketika melaut, di antaranya adalah:

- Ikan paus (Balaenoptera borealis) yang terdampar, menandakan akan adanya perubahan musim, baik dari musim hujan ke musim kemarau maupun sebaliknya dari musim kemarau ke musim hujan.

- Banyaknya burung murai besi (Heterophasia picaoides) yang beterbangan di atas laut, menandakan akan adanya perubahan musim, baik dari musim hujan ke musim kemarau maupun sebaliknya dari musim kemarau ke musim hujan, selain itu, menandakan juga bahwa di laut sedang banyak ikan sehingga sangat baik untuk melaut.

- Lauk motah (banyaknya gerakan ikan di laut), menandakan akan datangnya bencana berupa caah laut 'banjir laut', sehingga masyarakat sekitar pantai harus waspada.

- Impun ka muara 'ikan impun menuju ke muara', menandakan datangnya masa panen ikan impun, biasanya terjadi setiap tanggal 25 bulan Hijriah. Pada saat seperti ini masyarakat berbondong-bondong pergi ke muara untuk menangkap ikan impun, acara ini disebut nyalawena.

Sementara itu masyarakat petani juga memiliki pengetahuan lokal yang berhubungan dengan gejala-gejala alam dalam aktivitas pertanian mereka, di antaranya:

\section{Pengetahuan tentang Jenis-jenis Padi}

Di wilayah Kabupaten Cianjur padi merupakan tanaman utama yang ditanam oleh petani. Bahkan sudah terkenal bahwa Cianjur merupakan salah satu penghasil padi terbaik di Indonesia. Tentunya di sini banyak jenis padi yang pernah tumbuh dan ditanam oleh petani, jenis-jenis padi tersebut adalah sebagai berikut:

- Jenis-jenis padi yang bisa dipanen tiga kali dalam satu tahun, di antaranya adalah: padi IR, segon, barunday, manolin, dan nilek.

- Jenis padi yang bisa dipanen dua kali dalam setahun, yaitu: padi cere dan pandan wangi.

- Padi ketan, yaitu padi yang ditanam di sawah namun agak lain dengan jenisjenis padi yang tadi. Padi ketan biasanya dikonsumsi atau dijual, dihidangkan secara khusus karena rasanya yang lebih gurih serta lebih pekat.

\section{Pengetahuan tentang Gejala-gejala Alam}

Masyarakat petani di Kecamatan Cidaun, telah mengenal gejala-gejala alam yang berkaitan dengan aktivitas mereka sehari-hari, terutama ketika mau bertani. Pengetahuan masyarakat petani di 
Kecamatan Cidaun tentang gejala-gejala alam, di antaranya sebagai berikut.

- Munculnya bintang wuluku menandakan akan datangnya waktu ngijih 'musim hujan'. Kalau sudah muncul bintang wuluku biasanya para petani bersiap-siap untuk segera menanam padi.

- Terdengarnya suara cacing atau turaes (semacam binatang serangga), menandakan akan datangnya musim kemarau, biasanya akan terjadi angin yang cukup besar, kesusahan air, kekeringan, rumput mengering sehingga tidak baik untuk bertani.

- Rumput memerah, menandakan akan datangnya musim kemarau panjang, biasanya pada waktu ini masyarakat mengalami kekeringan dan kesusahan mendapatkan air, serta tidak bisa bertani.

- Bintang di langit terang benderang (bentang baranang), menandakan akan terjadinya musim kemarau, biasanya terjadi pada bulan April, sehingga tidak baik untuk melakukan tani di sawah, karena sumber air berkurang.

- Matahari bergerak ke sebelah selatan, menandakan akan terjadinya perubahan musim, yaitu mulai datangnya musim hujan. Para petani pun bersiap untuk segera menggarap sawahnya.

- Embun pagi berubah (ibun munggah peta), menandakan akan terjadinya musim kemarau yang panjang, bisa terjadi kurang lebih selama tujuh bulan. Ini menandakan bahwa kekeringan akan melanda masyarakat.

- Awan di langit mulai mendung, menandakan akan segera turun hujan, cuaca menjadi dingin, cocok untuk segera bercocok tanam.

\section{Pengetahuan tentang Dunia Flora}

Masyarakat Cidaun memiliki pengetahuan lokal yang terkait dengan aneka tumbuhan dan manfaatnya. Pengetahuan ini diperoleh secara turun temurun dari leluhur mereka melalui sistem pewarisan secara oral. Beberapa pengetahuan lokal masyarakat setempat mengenai aneka tumbuhan dan manfaatnya antara lain:

- Kayu jati; merupakan tanaman yang tumbuh di hutan, ditanam dan dipelihara untuk dijadikan bahan bangunan.

- Kayu pinus; jenis tanaman yang tumbuh di hutan, biasanya ditanam untuk dipergunakan sebagai bahan bangunan atau bahan pembuatan korek api.

- Pungpurutan; tanaman yang biasanya tumbuh di ladang dan di pekarangan rumah. Menurut pengetahuan masyarakat setempat, daun dari tanaman ini dapat digunakan sebagai obat diare.

- Buntiris; jenis tanaman perdu yang banyak tumbuh di ladang maupun di pekarangan rumah. Burintis merupakan tanaman obat yang daunnya dapat digunakan sebagai obat untuk menurunkan suhu badan.

- Kiurat; tanaman yang tumbuh di daerah dataran, daunnya dapat digunakan sebagai obat luka.

- Daun reundeu; daun dari pohon reundeu yang hidup di daratan. Daun ini dapat dipergunakan untuk mengobati kencing batu.

- Daun sudia; merupakan tanaman yang dapat digunakan sebagai tanaman obat penyakit campak, biasanya hidup di daratan.

- Jahe; tanaman yang tumbuh di daratan, bisa dibudidayakan di kebun, digunakan sebagai bahan obat, bumbu dapur, serta dibuat minuman.

- Keji beling; tanaman yang tumbuh di daerah daratan, dapat dipergunakan untuk mengobati kencing batu.

- Ubi kayu; tanaman yang dibudidayakan untuk dikonsumsi maupun sebagai komoditi untuk diperjualbelikan. Tanaman ini biasanya ditanam di kebun atau di ladang. 
- Panil; tanaman yang digunakan sebagai bahan pembuat minuman, bumbu dapur yang berfungsi untuk mengharumkan masakan.

- Ubi jalar; tanaman ubi-ubian yang hidup di daerah daratan, dibudidayakan untuk dikonsumsi dan dijual.

- Kapol; tanaman yang hidup di daerah daratan. Kapol ini biasa digunakan oleh ibu-ibu yang mempunyai kebiasaan "menyirih" sebagai bumbunya.

- Taruk paku atau pakis; tanaman yang tumbuh di daerah daratan, biasanya hanya sebagai tanaman hias.

- Kacang tanah; tanaman yang hidup di daerah daratan, ditanam untuk dikonsumsi atau dijual.

- Kina; tanaman yang tumbuh di daerah daratan, terutama di hutan, bisa dipergunakan sebagai tanaman obat dan kayu bakar.

- Pohpohan; tanaman yang tumbuh secara liar di hutan, biasanya dimakan sebagai lalapan.

- Babakoan; tanaman yang tumbuh di pinggir pantai secara liar, dapat dipergunakan untuk obat luka atau sebagai tanaman yang dapat menahan abrasi air laut.

- Bakung; tanaman yang hidup di pinggir pantai sebagai tanaman hias, atau sebagai penahan abrasi air laut. Tanaman ini biasanya tumbuh secara liar.

- Pandan laut; tanaman yang tumbuh di daerah pantai berguna untuk menahan abrasi air laut atau dijadikan bahan dasar untuk anyam-anyaman. Tanaman ini tumbuh secara bebas atau dibudidayakan.

- Rasamala; tanaman yang tumbuh di hutan, dapat dipergunakan sebagai bahan bangunan, atau pucuk daunnya bisa dikonsumsi sebagai lalapan.

- Putat; tanaman yang tumbuh di daerah daratan, daunnya dapat dimakan sebagai lalap.
- Gandaria; tanaman yang tumbuh di daerah daratan, buahnya dapat dipergunakan sebagai bahan untuk membuat sambal.

- Bunut; tanaman yang tumbuh di daerah daratan, daunnya dapat dimakan sebagai lalap.

- Karet; tanaman yang tumbuh di hutan, biasanya dibudidayakan sebagai tanaman yang diambil getahnya untuk bahan dasar pembuat karet.

- Kelapa; tanaman yang tumbuh di daerah pantai maupun dataran tinggi, lebih subur ditanam di pantai. Buah kelapa biasa digunakan sebagai bahan makanan, bumbu, dan bahan untuk membuat gula. Daunnya digunakan untuk membuat janur dan bungkus ketupat. Batangnya digunakan sebagai bahan bangunan.

- Cengkeh; tanaman yang dibudidayakan, di tanam di daerah daratan. Tanaman ini dapat digunakan sebagai bahan pembuat rokok, bumbu, dan obat.

- Kawung 'pohon enau'; tanaman yang hidup di daerah daratan, dapat digunakan sebagai bahan dasar pembuat gula (dari air niranya), aci (pohonnya), dan manisan (buahnya).

- Mahoni; tanaman yang tumbuh di hutan, dapat dipergunakan sebagai bahan bangunan dan kayu bakar.

- Pala; tanaman yang tumbuh di daerah daratan, dapat dipergunakan sebagai bumbu, obat, makanan, dan minuman.

- Kopi; tanaman yang tumbuh di daerah daratan, dapat dipergunakan sebagai bahan dasar untuk membuat minuman.

\section{Pengetahuan tentang Dunia Fauna}

Masyarakat Cidaun Cianjur Selatan

memiliki pengetahuan lokal mengenai dunia fauna (hewan), baik hewan yang hidup di air, darat, maupun udara yang ada di sekeliling mereka. Pengetahuan tentang dunia fauna ini dikenal baik oleh masyarakat petani maupun nelayan di daerah Kabupaten Cianjur. 
- Hayam pelung; hewan yang dilindungi oleh pemerintah melalui Perbup, karena merupakan hewan khas yang ada di Cianjur, dapat digunakan sebagai hobi sebab suaranya sangat nyaring dan dapat juga untuk dikonsumsi atau dijual, hidup di darat dan telah dibudidayakan oleh masyarakat, banyak terdapat di Kecamatan Warungkondang.

- Surili; sama halnya dengan hayam pelung merupakan hewan khas Kabupaten Cianjur yang dilindungi melalui Perbup, hidup liar di darat, di hutan-hutan.

- Lubang; salah satu jenis ikan yang hidup di sungai secara bebas, biasanya dipancing oleh masyarakat untuk dikonsumsi.

- Ikan soro; salah satu jenis ikan yang hidup di sungai secara bebas namun ada yang sudah dibudidayakan, dapat digunakan untuk dikonsumsi dan dijual.

- Ikan impun; ikan khas yang terdapat di Pantai Apra, hidup dari laut menuju ke muara, ini ada setiap tanggal 25 bulan Hijriah, masyarakat berbondongbondong menangkapnya dengan cara disirib 'dijala' atau disair, sebelumnya selalu diadakan upacara tradisional yang disebut nyalawena, hasilnya untuk dikonsumsi, dijual, bahkan dibuat makanan tradisional bernama Jalangkring (dendeng ikan impun). Selain itu, ada juga ikan impun yang hidup di air tawar, ini biasanya hidup secara bebas, ditangkap masyarakat untuk dikonsumsi.

- Genggehek atau ikan tagih atau gurame; salah satu ikan yang hidup di sungai secara bebas, dipancing untuk dikonsumsi, namun ada juga yang telah dibudidayakan untuk dikonsumsi dan dijual.

- Ikan nila; salah satu jenis ikan yang hidup di sungai, ada yang hidup bebas, ada juga yang sudah dibudidayakan untuk dikonsumsi dan dijual.
- Lele; salah satu jenis ikan yang hidup di sungai secara bebas, biasanya dipancing masyarakat untuk dikonsumsi, namun ada juga yang telah dibudidayakan untuk dikonsumsi dan dijual.

- Beunteur; salah satu jenis ikan kecil, banyak hidup di sungai secara bebas, biasanya dipancing masyarakat untuk dikonsumsi.

- Kehkel; salah satu jenis ikan yang hidup di sungai secara bebas, biasanya dipancing masyarakat untuk dikonsumsi.

- Udang; salah satu jenis ikan yang hidup di sungai dan di laut secara bebas, biasanya ditangkap masyarakat untuk dikonsumsi, namun ada juga udang yang telah dibudidayakan untuk dikonsumsi dan dijual.

- Paus; hewan yang hidup di laut secara bebas, ditangkap oleh nelayan untuk dikonsumsi dan dijual.

- Lumba-lumba; hewan yang hidup di laut secara bebas, menurut kepercayaan hewan ini tidak boleh ditangkap ataupun dikonsumsi karena beranggapan bahwa ikan lumba-lumba adalah ikan penolong di tengah laut.

\section{Pengetahuan tentang Alam Gaib}

Masyarakat Cidaun mengenal adanya alam lain di luar alam fisik, yaitu alam ghaib (goib). Masyarakat setempat mempercayai bahwa di setiap tempat ada penghuninya, seperti di antaranya, sebagai berikut.

- Alam jin, merupakan alam gaib yang sangat dipercaya keberadaannya, penghuninya adalah jin, jurig, ririwa, setan, dan kunti. Alam ini dapat menimbulkan rasa takut kepada manusia yang tidak teguh keimanannya. Kekuatan-kekuatan yang ada pada makhluk penghuni alam ini sering digunakan untuk hal yang negatif seperti santet dan pelet, atau digunakan untuk membunuh orang atau memikat orang. 
- Negara di bawah laut, merupakan alam yang dipercaya keberadaannya, bahkan membentuk sebuah kerajaan di bawah laut, berada di Laut Selatan yang dipimpin oleh seorang ratu, yaitu Ratu Laut Pantai Selatan, Nyai Ratu Roro Kidul. Negara di bawah laut ini dihuni juga oleh bangsa-bangsa jin dan ponggawa-ponggawa dari kerajaan Nyai Roro Kidul. Dengan adanya kepercayaan ini, masyarakat yang berada di sekitar pantai Selatan setiap tahunnya selalu mengadakan upacara ritual persembahan kepadanya.

\section{Pengetahuan Lokal sebagai Wujud A daptasi (Bahasan)}

Bruce Mitchell et al. (2000) dalam sebuah bukunya yang bertajuk Pengelolaan Sumberdaya dan Lingkungan, secara khusus membahas sistem pengetahuan lokal pada salah satu subbab pembahasan. Menurutnya, konsep sistem pengetahuan lokal berakar dari sistem pengetahuan dan pengelolaan lokal atau tradisional. Konsep ini terkait dengan konsep-konsep mengenai masyarakat adat, masyarakat lokal, atau masyarakat tradisional.

Definisi tentang masyarakat asli atau lokal cukup beragam. Ade Makmur K. (2009), dalam sebuah makalahnya yang berjudul "Keberadaan Masyarakat Adat di Tengah Arus Modernisasi" menjelaskan, bahwa masyarakat adat atau oleh PBB disebut Indigenous Peoples, adalah pewaris dan pelaksana kebudayaan yang unik dan bentuk-bentuk hubungan dengan sesama manusia dan lingkungan, dengan mempertahankan sifat-sifat sosial, ekonomi dan politiknya yang berbeda dengan masyarakat pada umumnya di mana mereka tinggal. Merujuk pada definisi masyarakat adat oleh PBB tersebut, dalam konteks Indonesia setidaknya dikenal tiga kategori masyarakat adat, yaitu:

- Kelompok sosial yang terikat oleh tradisi, namun tidak terikat oleh kesatuan tempat tinggal yang sama.
- Kelompok sosial yang terikat oleh tradisi dan masih mengamalkan ketentuan leluhur, tetapi diberi kelonggaran memilih kesatuan tempat tinggal.

- Kelompok sosial yang terikat, dan menjalankan tradisi leluhur dengan ketat, serta terikat oleh kesatuan tempat tinggal yang sama dalam kelompok-kelompok yang kecil.

Dari ketiga kategori tersebut, kategori kesatu dan kedua lebih dikenal sebagai masyarakat tradisional dan kategori ketiga dikenal sebagai masyarakat adat. Adapun sebutan yang umum bagi mereka yang termasuk kategori tiga, dikenal dengan pelbagai istilah: seperti orang gunung (highlanders), orang asli (aborigines), orang hutan (forest people), pribumi (natives), dan masyarakat terasing (komunitas adat terpencil).

Nygren (1999) mengemukakan pengetahuan lokal merupakan istilah yang problematik. Pengetahuan lokal dianggap tidak ilmiah, sehingga pengetahuan lokal tersebut dibedakan dengan pengetahuan ilmiah yang dikenalkan oleh dunia barat. Titik temu antara pengetahuan lokal yang tidak ilmiah dan yang ilmiah tersebut keduanya berada pada bagaimana cara memahami dunia mereka sendiri. Pengetahuan lokal dapat ditelusuri dalam bentuk pragmatis maupun supranatural. Pengetahuan dalam bentuk pragmatis menyangkut pengetahuan tentang kaitan pemanfaatan sumberdaya alam, dan dalam bentuk supranatural.

Kondisi semacam ini nampak pada mas yarakat Cidaun yang dapat dilihat pada sistem kepercayaan mereka. Pengetahuan mereka tentang alam gaib beserta upacaraupacara tradisional yang mengiringi aktivitas pertanian maupun kenelayanan, merupakan respons dari masyarakat dalam menghadapi berbagai fenomena alam, baik yang nyata maupun tidak. Dalam sistem pengetahuan lokal mereka, mereka percaya bahwa di samping lingkungan alam fisik yang mereka tempati, terdapat alam lain yang dihuni oleh makhluk gaib serta 
kekuatan-kekuatan supranatural yang menentukan berhasil tidaknya aktivitas pencaharian mereka, baik sebagai petani maupun nelayan. Jampi-jampi dan mantera yang mengagungkan dan memuliakan makhluk-makhluk gaib merupakan perwujudan sistem pengetahuan lokal masyarakat tentang alam gaib.

Sejalan dengan perubahan budaya yang menerpa kehidupan masyarakat, masyarakat juga secara perlahan mengembangkan pengetahuan yang telah diwariskan, dan kemudian menciptakan metode untuk membangun pengetahuan. Penciptaan pengetahuan itu pada dasarnya merupakan cara-cara atau teknologi asli (indigenous ways) guna mendayagunakan sumber daya alam bagi kelangsungan kehidupan masyarakatnya. Oleh karena itu, masyarakat mengembangkan suatu sistem pengetahuan dan teknologi yang asli yang mencakup berbagai macam cara untuk mengatasi kehidupan. Kearifan lokal yang sedemikian itu, umumnya berbentuk tradisi lisan, dan lebih banyak berkembang di daerah perdesaan. Pengetahuan itu dikembangkan karena adanya kebutuhan untuk menghayati, mempertahankan, dan melangsungkan hidup sesuai dengan situasi, kondisi, kemampuan dan nilai-nilai yang dihayati di dalam masyarakatnya. Oleh karena itu, pengetahuan lokal menjadi bagian dari cara hidup mereka yang arif, agar dapat memecahkan segala permasalahan hidup yang mereka hadapi, sehingga mereka dapat melangsungkan kehidupannya, bahkan, dapat berkembang secara berkelanjutan. (Kartawinata, 2011: xi).

Konsep sistem pengetahuan lokal, kearifan lokal atau kearifan tradisional (indigenous knowledge system) adalah pengetahuan yang khas milik suatu masyarakat atau budaya tertentu yang telah berkembang lama sebagai hasil dari proses hubungan timbal-balik antara masyarakat dengan lingkungannya. Jadi, konsep sistem kearifan lokal berakar dari sistem pengetahuan dan pengelolaan lokal atau tradisional. Karena hubungan yang dekat dengan lingkungan dan sumber daya alam, masyarakat lokal, tradisional, atau asli, melalui "uji coba" telah mengembangkan pemahaman terhadap sistem ekologi dimana mereka tinggal yang telah dianggap mempertahankan sumber daya alam, serta meninggalkan kegiatankegiatan yang dianggap merusak lingkungan (Mitchell, 2003).

Kondisi ini kemudian menyebabkan munculnya respon dan upaya untuk beradaptasi dalam menghadapi krisis. Adaptasi dan perubahan adalah dua sisi mata uang yang tidak terpisahkan bagi makhluk hidup. Adaptasi berlaku bagi setiap makhluk hidup dalam menjalani hidup dalam kondisi lingkungan yang senantiasa berubah. Bennet (1976) memandang adaptasi sebagai suatu perilaku responsif manusia terhadap perubahan-perubahan lingkungan yang terjadi. Perilaku responsif tersebut memungkinkan mereka dapat menata sistem-sistem tertentu bagi tindakan atau tingkah lakunya, agar dapat menyesuaikan diri dengan situasi dan kondisi yang ada. Perilaku tersebut di atas berkaitan dengan kebutuhan hidup, setelah sebelumnya melewati keadaan-keadaan tertentu dan kemudian membangun suatu strategi serta keputusan tertentu untuk menghadapi keadaan-keadaan selanjutnya. Dengan demikian, adaptasi merupakan suatu strategi yang digunakan oleh manusia dalam masa hidupnya guna mengantisipasi perubahan lingkungan baik fisik maupun sosial.

Adaptasi merupakan salah satu bagian dari proses evolusi kebudayaan, yakni proses yang mencakup rangkaian usaha-usaha manusia untuk menyesuaikan diri atau memberi respon terhadap perubahan lingkungan fisik maupun sosial yang terjadi secara temporal. Sebagai suatu proses perubahan, adaptasi dapat berakhir dengan sesuatu yang diharapkan atau tidak diharapkan. Oleh karenanya, adaptasi merupakan suatu sistem interaksi yang berlangsung terus antara manusia dengan manusia, dan antara manusia dengan 
ekosistemnya. Dengan demikian, tingkah laku manusia dapat mengubah suatu lingkungan atau sebaliknya, lingkungan yang berubah memerlukan suatu adaptasi yang selalu dapat diperbaharuhi agar manusia dapat bertahan dan melangsungkan kehidupan di lingkungan tempat tinggalnya (Bennett, 1976).

Masyarakat dengan pengetahuan dan kearifan lokal telah ada di dalam kehidupan masyarakat semenjak zaman dahulu mulai dari zaman prasejarah sampai sekarang ini. Kearifan tersebut merupakan perilaku positif manusia dalam berhubungan dengan alam dan lingkungan sekitarnya yang dapat bersumber dari nilainilai agama, adat istiadat, petuah nenek moyang atau budaya setempat yang terbangun secara alamiah dalam suatu komunitas masyarakat untuk beradaptasi dengan lingkungan di sekitarnya. Perilaku ini berkembang menjadi suatu kebudayaan di suatu daerah dan akan berkembang secara turun-temurun. Secara umum, budaya lokal atau budaya daerah dimaknai sebagai budaya yang berkembang di suatu daerah, yang unsur-unsurnya adalah budaya suku-suku bangsa yang tinggal di daerah itu. I Ketut Gobyah dalam "Berpijak pada Kearifan Lokal" mengatakan bahwa kearifan lokal (local genius) adalah kebenaran yang telah mentradisi atau ajeg dalam suatu daerah. Kearifan lokal merupakan perpaduan antara nilai-nilai suci firman Tuhan dan berbagai nilai yang ada. Kearifan lokal terbentuk sebagai keunggulan budaya masyarakat setempat maupun kondisi geografis dalam arti luas. Meskipun bernilai lokal tetapi nilai yang terkandung di dalamnya dianggap sangat universal. Dengan demikian, sistem pengetahuan lokal masyarakat tersebut dapat diintegrasikan dalam analisis risiko lingkungan dan mitigasi bencana alam berlandaskan kajian ilmu pengetahuan atau pandangan etik (Johan, 2009).

Sejak ratusan bahkan ribuan tahun yang lalu, nenek moyang bangsa Indonesia telah memiliki sistem pengetahuan yang sangat kaya, mulai dari sistem astronomi, perhitungan tanggal, cara bercocok tanam dan pengetahuan yang lain. Demikian pula halnya dengan masyarakat Cidaun di kawasan Cianjur Selatan, Kabupaten Cianjur telah memiliki pengetahuan lokal yang dibentuk dari pengalaman hidupnya dalam berinteraksi dengan alam, baik alam fisik lingkungan maupun alam spiritual. Pengetahuan lokal masyarakat Cidaun mengenai berbagai gejala alam, baik yang berhubungan dengan aktivitas kenelayanan maupun pertanian menjadi pedoman mereka dalam melakukan aktivitas mata pencaharian.

Bentuk respon yang dilakukan oleh komunitas lokal masyarakat nelayan dan petani di Cidaun ini menjelaskan wujud adaptasi terhadap perubahan lingkungan. Hal tersebut sesuai dengan konsep strategi adaptasi yang dinyatakan oleh Bennett (1976), sebagai suatu tindakan spesifik yang dipilih oleh individu atau masyarakat di dalam proses pengambilan keputusan, dengan suatu derajat keberhasilan yang dapat diprediksi.

\section{D.PENUTUP}

Dalam konsep ekologi kebudayaan, manusia merupakan salah satu subsistem dalam ekosistem lingkungan. Dengan demikian manusia adalah satu kesatuan terpadu dengan lingkungannya dan di antaranya terjalin suatu hubungan fungsional sedemikian rupa. Dalam hubungan fungsional tersebut manusia dan lingkungan terdapat saling ketergantungan dan saling pengaruh, yang pada akhirnya akan berpengaruh pada ekosistem secara keseluruhan.

Sebagai makhluk hidup, manusia paling mampu beradaptasi dengan lingkungannya dan selalu berupaya untuk memanfaatkan sumber-sumber yang ada untuk menunjang kebutuhan hidupnya. Hal itu menyebabkan adanya ikatan antara manusia dengan lingkungan alamnya. Ikatan itu memberikan pengalaman dan pengetahuan serta pikiran pada manusia, bagaimana harus memperlakukan alam 
lingkungan yang mereka miliki. Masyarakat Cidaun memiliki kekayaan pengetahuan lokal yang sangat menunjang aktivitas mata pencaharian mereka, baik sebagai nelayan maupun petani. Pengetahuan lokal yang dimiliki oleh masyarakat Cidaun merupakan strategi adaptasi mereka dalam menanggapi berbagai fenomena alam yang dihadapi dalam kehidupan sehari-hari.

\section{DAFTAR SUMBER}

\section{Buku}

Bennet, J.W. 1976.

The Ecological Transition: Cultural Anthropology and Human Action. New York: Pergamon Press Inc.

Mitchell, Bruce., Bakti Setiawan, Dwita Rahmi. 2000.

Pengelolaan Sumberdaya dan Lingkungan. Yogyakarta: Gadjah Mada University Press.

Dahuri, R., Rais, J., Ginting, S.P., \& Sitepu, M.J. (1996).

Pengelolaan Sumber Daya Wilayah Pesisir dan Lautan Secara Terpadu. Jakarta: Pradnya Paramitha.

Kartawinata, Ade M. (ed). 2011.

Kearifan Lokal di Tengah Arus Modernisasi. Diterbitkan oleh Pusat Penelitian dan Pengembangan Kebudayaan Badan Pengembangan Sumber Daya Kebudayaan dan Pariwisata Kementerian Kebudayaan dan Pariwisata Republik Indonesia, Jakarta.

Kusnadi. (2009)

Keberdayaan Nelayan \& Dinamika Ekonomi Pesisir. Yogyakarta: Lembaga Penelitian Universitas Jember dan ArRuzz Media.

Nasruddin, 2011.

"Patorani: Sang Pemburu Ikan Terbang", dalam Buku Kearifan Lokal di Tengah Arus Modernisasi. Diterbitkan oleh Pusat Penelitian dan Pengembangan Kebudayaan Badan Pengembangan Sumber Daya Kebudayaan dan Pariwisata
Kementerian Kebudayaan dan Pariwisata Republik Indonesia, Jakarta.

Nygren, A. 1999.

"Local Knowledge in the EnvironmentDevelopment Discourse: From Dicotomies to Situated Knowledge", Critique of Anthropology 19 (3): 267288 .

Suparlan, Parsudi. 2005.

Suku bangsa dan Hubungan Antar Sukubangsa. Jakarta: Yayasan Pengembangan Kajian Ilmu Kepolisian.

Firth, Raymond. 1966.

Tjiri-tjiri dan Alam Hidup Manusia. Terj. B. Mochtan dan A. Puspanegara. Bandung: Tarsito.

\section{Jurnal}

Antropologi Indonesia (Majalah Antropologi Sosial dan Budaya Indonesia), No. 55, XXII, 1998, Penerbit Jurusan Antropologi FISIP UI, Jakarta.

Jurnal Analisis CSIS. 1995. Kebudayaan, Kearifan Tradisional dan Pelestarian Lingkungan. CSIS Jakarta.

Makara, Sosial Humaniora, Vol. 16, No. 1, Juli 2012: 68-78.

\section{Makalah}

Kartawinata, Ade M. "Keberadaan Komunitas Adat di Tengah Arus Globalisasi". Makalah disampaikan pada Workshop dan Festival Komunitas Adat "Mewujudkan Indonesia Kreatif melalui Pemberdayaan Komunitas Adat", diselenggarakan oleh Departemen Kebudayaan dan Pariwisata - Balai Pelestarian Sejarah dan Nilai Tradisonal Bandung tanggal 22 Juli 2009.

Purwana, Bambang H. Suta, "Naga": Modal Sosial dan Pola Interaksi Sosial Komunitas Kampung. Kertas Kerja Pelatihan Teknis Peneliti Nilai Budaya. Bandung 2004. 


\section{Surat Kabar}

Iskandar. Johan.

"Mitigasi Bencana Lewat Kearifan

Lokal", Kompas, 6 Oktober 2009.

\section{Internet}

Baharudin, Erwan.

Mahasiswa Pascasarjana Antropologi

Universitas Indonesia, Jakarta. Kearifan

Lokal, Pengetahuan Lokal dan

Degradasi Lingkungan.

http://www.esaunggul.ac.id/category/ep

aper/

Gobyah, I Ketut, "Berpijak pada Kearifan Lokal”, dalam http://www.balipos. co.id , didownload 17/9/03.

"Hak Masyarakat Adat: Ketegangan Antara Kewajiban Negara dan Realitas Kebutuhan: Studi Kasus Kasepuhan Sirnaresmi dan Citorek". Diakses dari http://www.scribd.com/ doc/36105858/Riset-Hak-MasyarakatAdat-Kasus-Kasepuhan-Naskah-Final 